\title{
Socioeconomic Investigation and Husbandry Management Practices of Native Sheep Rearing Farmers in Selected Areas of Bangladesh
}

\author{
Md. Ruhul Amin 1, *, Md. Ershaduzzaman", ${ }^{1,}$ S. M. Jahangir Hossain ${ }^{3}$, Md. Ahsanul Kabir ${ }^{3}$, \\ Gautam Kumar Deb ${ }^{3}$ \\ ${ }^{1}$ Conservation and Improvement of Native Sheep through Community and Commercial Farming (Component-A, Research 2nd Phase), \\ Bangladesh Livestock Research Institute, Dhaka, Bangladesh \\ ${ }^{2}$ Socioeconomic Research Division, Bangladesh Livestock Research Institute, Dhaka, Bangladesh \\ ${ }^{3}$ Biotechnology Division, Bangladesh Livestock Research Institute, Dhaka, Bangladesh
}

Email address:

ruhulaminbau@yahoo.com (Md. R. Amin)

${ }^{*}$ Corresponding author

To cite this article:

Md. Ruhul Amin, Md. Ershaduzzaman, S. M. Jahangir Hossain, Md. Ahsanul Kabir, Gautam Kumar Deb. Socioeconomic Investigation and Husbandry Management Practices of Native S Sheep Rearing Farmers in Selected Areas of Bangladesh. International Journal of Agricultural Economics. Vol. 5, No. 6, 2020, pp. 286-292. doi: 10.11648/j.ijae.20200506.17

Received: October 22, 2020; Accepted: November 5, 2020; Published: November 19, 2020

\begin{abstract}
The present research was design to explore the socioeconomic conditions, the existing husbandry management practices along with the problems and constraints of native sheep rearing farmers at the field level. The data was collected from purposively selected 11 upazilas of 6 districts in Bangladesh. The data was collected through a pre-tested interview schedule from 1768 sheep rearing farmers by using simple random sampling technique and analyzed descriptively. The research revealed that $52.65 \%$ of farmers were literate in the study areas and most of them $(32.52 \%)$ were studied classes 1 to 5 . The literacy rate of the sheep farmers was the highest in Nikhongchari and Subornochar upazilas. The main occupation of sheep rearing farmer was agriculture $(65.16 \%)$. However, the landholdings and annual income were found $122.01 \pm 8.85$ decimal and BDT 80 thousand respectively. The highest landholding and annual income were found in Subornochar (373.19 decimal) and Copanigonj upazillas (BDT 215 thousand) respectively. Moreover, Subornochar and Copanigonj upazilas were found rich in livestock assets than the other surveyed areas. The highest herd size of sheep per household found $76.61 \pm 8.90$ and $30.71 \pm 7.26$ in Copanigonj and Subornochar upazilas respectively. In all irrespective of areas, the herd size per household was found 13.27 \pm 1.23 . Among all types of sheep ewe $(56.47 \%)$ was the highest because farmers normally kept ewes for further reproduction, ram and wither were sold early in the market. Furthermore, the existing management practices of native sheep found poor irrespective of areas. Most of the farmers have no separated shed and $21.50 \%$ of them used cow shed as the housing of native sheep. Hence, the feeding system was mostly the entire free movement system (49.33\%) and the average time for field feeding was $9.33 \pm 0.05$ hours/day. The farmers used open land $(66.34 \%)$ and roadside $(61.53 \%)$ as pasture land for their sheep. The highest $43.15 \%$ of farmers reported a shortage of natural feeding land followed by disease and treatment $(41.00 \%)$ related problems. The organized efforts should be taken to incorporate a feasible and sustainable management system of native sheep and consequently to improve the socioeconomic conditions of rural poor farmers in Bangladesh.
\end{abstract}

Keywords: Native Sheep, Socioeconomic, Annual Income, Housing, Feeding System, Constraints

\section{Introduction}

The small ruminants (goat and sheep) play a very important role in the rural economy of Bangladesh by providing a source of employment, women empowerment and the tool for poverty alleviation [1]. Among the small ruminants, native sheep are important for production of meat in Bangladesh. The native sheep (Ovis aries) of Bangladesh originated from the wild Urial (Ovis orientalis vignei) of Asia 
[2]. There are 3.46 millions of sheep in Bangladesh [3]. Most of the sheep are indigenous reared Barind, Jamuna basin and Coastal areas with some crossbred and are capable of biannual lambing and multiple births [2]. Coastal region sheep are more potential than other regional sheep for commercial lamb production. The native sheep is an important source of income involving minimum investment, care and management [4]. Sheep is mostly thriving on naturally grown grasses, various crop residues like straws, stovers, stalks and cereal by-products [5]. However, more than $90 \%$ of the feed consumed by sheep are roughages and feeding systems mostly traditional, the sheep are reared on fallow lands, roadside, and canal sides [6]. Moreover, sheep in rural areas graze on aquatic weeds and grass without supplementation, therefore reduce growth and poor reproductive performance [7]. Furthermore, the native sheep is rearing mostly by the rural poor farmer without improved economic trait and management practices resulting in significant economic loss [8]. Regional sheep breeds are fundamental to the social and economic structure of rural communities; knowledge of rearing management is an essential contributor to both economic and environmental sustainability [9]. The native sheep are mainly reared by small and marginal farmers and has socioeconomic importance. Hence, the future economic growth and sustainability of rural poor mainly rural women will be addressed by rearing native sheep in the changed climatic condition. Considering these facts present research was designed to explore the socioeconomic status of sheep rearing farmers, the existing husbandry management practices along with problems and constraints of sheep farming at the farmers' level, which may contribute to improve management system and sustainable growth of native sheep rearing in the country as well as livelihoods of the farmer.

\section{Methodology}

\subsection{Selection of Study Areas}

The research was executed following the logical research methodology. At first, the problem was identified and relevant papers and documents were reviewed. For collecting the relevant data to fulfill the scope of the research, sheep populated 11 upazilas of 6 districts were selected purposively.

\subsection{Development of Interview Schedule}

The interview schedule was developed as objective-based, with a logical sequence and rationally. Both quantitative and qualitative formats of data collection were used to collect quantitative and qualitative data. Some open questions were included for acquiring qualitative data for determining people's estimation and feelings. Then the interview schedule was pre-tested and after necessary adjustment, the final interview schedule was developed.

\subsection{Estimation of Sample Size for the Survey}

The estimation of sample size is determined by available budget, time, manpower and sample. Considering these factors the number of samples for the survey was fixed as 400 for each of the district. However, the actual number of sample covered for necessary data a total of 1768 sheep rearing households were surveyed using simple random sampling technique. Table 1 shows the selected areas and numbers of sample size irrespective of areas.

Table 1. Selected study areas and sample size.

\begin{tabular}{|c|c|c|c|}
\hline SI. No. & District & Upazilla & Number of samples \\
\hline \multirow{2}{*}{1} & \multirow{2}{*}{ Naogaon } & Naogaon Sadar & 185 \\
\hline & & Mohadevpur & 252 \\
\hline \multirow{2}{*}{2} & \multirow{2}{*}{ Gaibandha } & Gaibandha Sadar & 180 \\
\hline & & Gobindogonj & 120 \\
\hline \multirow{2}{*}{3} & \multirow{2}{*}{ Tangail } & Tangail Sadar & 131 \\
\hline & & Bhuapur & 201 \\
\hline \multirow{2}{*}{4} & \multirow{2}{*}{ Sylhet } & Sylhet Sadar & 171 \\
\hline & & Balagonj & 164 \\
\hline \multirow{2}{*}{5} & \multirow{2}{*}{ Noakhali } & Subornochar & 243 \\
\hline & & Copanigonj & 112 \\
\hline \multirow[t]{2}{*}{6} & Bandarban & Nikhongchari & 9 \\
\hline & Total & & 1768 \\
\hline
\end{tabular}

\subsection{Data Collection}

The researcher has given careful attention to collect the data. The researcher selected the enumerator's and trained up them carefully to collect relevant data and made the process bias-free. The sheep rearing farmers were interviewed face to face by visiting the farm and the necessary data, views and opinions were recorded.

\subsection{Data Input, Processing and Analysis}

After collecting, the data were inputted to MS Access as per output tables. Then both qualitative and quantitative data were summarized and analyzed. Mostly, the data were analyzed descriptively using SPSS (version 20.0).

\section{Results and Discussions}

\subsection{The Educational Status of Sheep Rearing Farmers}

The educational status of sheep rearing farmers is shown in Table 1. From the study, it was revealed that $52.65 \%$ of farmers were found literate and $47.34 \%$ were found illiterate irrespective of all study areas. Among literate farmers, most of the farmers (32.52\%) belonged to class 1-5 level followed by $14.59 \%$ in class $6-10$ and only $5.54 \%$ SSC/equivalent or more. Literacy rate of the sheep farmers was the highest in Nikhongchari (100\%) followed by Subornochar upazila $(72.02 \%)$ and the lowest in Tangail sadar (27.48\%) upazila. Hence, the major dropout occurred at the primary level. In the previous study, it was found that $60 \%$ of sheep rearing farmers are at the primary level of education which differs from the present finding [7]. Similar result found in the study that $38 \%$ of farmers complete the primary education level [10]. 
Table 2. Educational status of sheep farmers.

\begin{tabular}{lllllll}
\hline S1. No. & Upazilla & Illiterate (\%) & Literate (\%) & Class 1-5 (\%) & Class 6-10 (\%) & SSC/Equivalent or more (\%) \\
\hline 1 & Naogaon Sadar & 54.59 & 45.41 & 30.27 & 8.65 & 6.49 \\
2 & Mohadevpur & 32.54 & 67.46 & 40.87 & 21.83 & 4.36 \\
3 & Gaibandha Sadar & 37.22 & 55.00 & 37.22 & 13.89 & 3.89 \\
4 & Gobindogonj & 60.00 & 40.00 & 19.17 & 13.33 & 5.83 \\
5 & Tangail Sadar & 72.52 & 27.48 & 18.32 & 9.92 & 3.82 \\
6 & Bhuapur & 70.15 & 29.85 & 14.93 & 9.45 & 5.97 \\
7 & Sylhet Sadar & 41.52 & 58.48 & 45.61 & 15.79 & 1.17 \\
8 & Balagonj & 40.24 & 59.76 & 43.29 & 19.63 & 1.22 \\
9 & Subornochar & 27.98 & 72.02 & 40.33 & 20.58 & 8.11 \\
10 & Copanigonj & 60.72 & 39.29 & 21.43 & 9.82 & 44.44 \\
11 & Nikhongchari & 0.00 & 100 & 22.22 & 33.33 & 5.54 \\
\hline
\end{tabular}

\subsection{The Occupational Status of Sheep Farmer}

Irrespective of the study areas, occupational status of farmers is shown in Figure 1. From the study, it was found that most of the sheep rearing farmers $(65.16 \%)$ were involved in agriculture as their main occupation. However, business $(16.12 \%)$, service holder $(2.60 \%)$, day laborer $(5.26 \%)$ and housewife $(3.11 \%)$ were found as the main occupation in the study areas. The previous study reported that $77 \%$ of farmers had agriculture as primary occupation followed by business $(15 \%)$ which is almost similar to the present study [10].

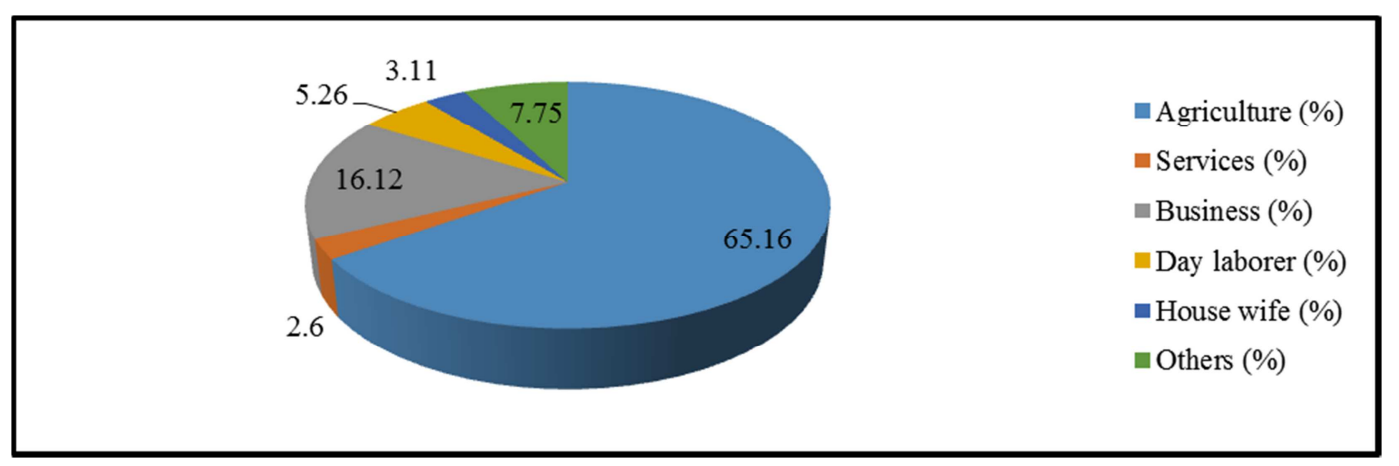

Figure 1. Occupational status of sheep farmer.

\subsection{Landholdings of Sheep Rearing Farmers}

The landholdings of sheep rearing farmers are presented in Figure 2. The landholding per household was the highest in Subornochar (373.19 decimal) upazila followed by Nikhongchari (363.33 decimal) and Copanigonj (335.8 decimal) because of char and hilly areas and lowest in
Naogaon Sadar (25.17 decimal). However, overall landholding per household was 122.01 decimal irrespective of the study areas. Previously it was found that the average farm size varied between small and medium farmers and small farmers are resource-poor with small landholdings [11].

\begin{tabular}{|c|c|c|c|}
\hline - Naogaon Sadar & $\square$ Mohadevpur & $\square$ Gobindogonj & -Tangail Sadar \\
\hline Bhuapur & $\square$ Sylhet Sadar & Balagonj & $\square$ Subornochar \\
\hline$\square$ Companigonj & Nikhongchari & $\square$ Gaibandha Sa & All mean \\
\hline
\end{tabular}

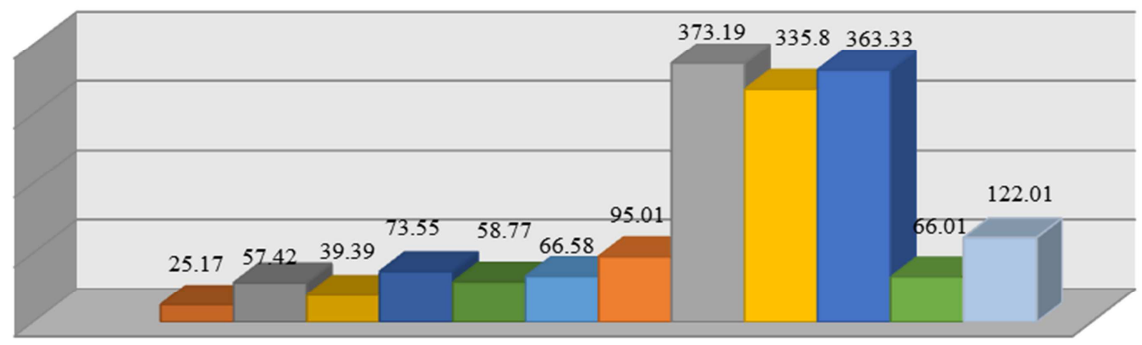

Mean land holdings (Decimal)

Figure 2. The landholdings of sheep rearing farmers. 


\subsection{Annual Family Income of Sheep Rearing Farmers}

The annual family income of sheep rearing farmers is shown in Figure 3. Irrespective of the areas, the annual income the farmer was BDT 80 thousand. The highest annual income was found in Copanigonj (BDT 215 thousand) upazilla. This is because the farmer of Companigonj upazila has a higher landholding and rich in livestock assets (Figure 2 and Table 3). However, the annual family income was found the lowest in Naogaon sadar upazila (BDT 37 thousand) because the landholding and livestock assets of the upazila were lower (Figure 2 and Table 3). The annual household income of the sheep farmer varied to BDT 132873 to 320800 found in the previous study which differs from the present study may be for different study areas [11]. However, another research reported that the annual income of small ruminant rearing farmer ranged to BDT 50 thousand to 400 thousand [12].

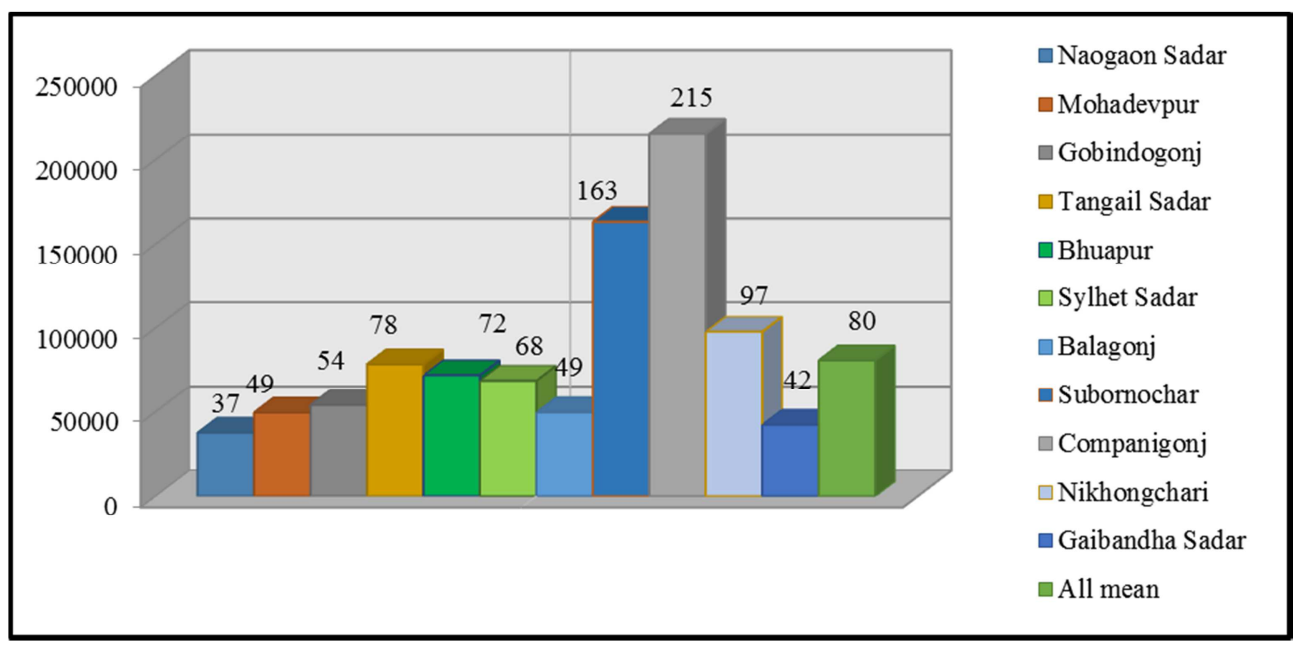

Figure 3. The annual income of sheep rearing farmer.

\subsubsection{Types of Livestock Reared in the Study Areas}

Irrespective of the study areas, the number of goats, cattle, buffalo, poultry, duck and pigeon per household were found $1.26 \pm 0.09,3.57 \pm 0.32,2.54 \pm 0.48,8.62 \pm 1.21,5.45 \pm 0.88$, and $1.41 \pm 0.15$ respectively (Table 3). Copanigonj and Subornochar upazila of Noakhali district was found rich in livestock assets may be for land holdings and a favorable environment.

Table 3. Different livestock animals/birds holdings per household.

\begin{tabular}{|c|c|c|c|c|c|c|}
\hline Upazila & Goat $($ Mean \pm SE) & $\begin{array}{l}\text { Cattle } \\
(\text { Mean } \pm \text { SE })\end{array}$ & $\begin{array}{l}\text { Buffalo } \\
(\text { Mean } \pm \text { SE })\end{array}$ & $\begin{array}{l}\text { Poultry } \\
(\text { Mean } \pm \text { SE })\end{array}$ & $\begin{array}{l}\text { Duck } \\
(\text { Mean } \pm \text { SE })\end{array}$ & $\begin{array}{l}\text { Pigeon } \\
(\text { Mean } \pm \text { SE })\end{array}$ \\
\hline Naogaon Sadar & $0.39 \pm 0.10$ & $0.98 \pm 0.10$ & $0.03 \pm 0.02$ & $4.6 \pm 0.28$ & $2.10 \pm 0.16$ & $0.65 \pm 0.33$ \\
\hline Mohadevpur & $0.63 \pm 0.11$ & $0.87 \pm 0.10$ & $0.02 \pm 0.01$ & $3.43 \pm 0.40$ & $1.86 \pm 0.26$ & $0.63 \pm 0.42$ \\
\hline Gobindogonj & $0.58 \pm 0.15$ & $2.19 \pm 0.19$ & $0 \pm 0.00$ & $8.73 \pm 0.77$ & $2.47 \pm 0.36$ & $1.19 \pm 0.59$ \\
\hline Tangail Sadar & $0.93 \pm 0.15$ & $1.06 \pm 0.13$ & $0.04 \pm 0.04$ & $3.08 \pm 0.32$ & $3.03 \pm 0.40$ & $0.56 \pm 0.25$ \\
\hline Bhuapur & $1.17 \pm 0.18$ & $1.57 \pm 0.17$ & $0.01 \pm 0.01$ & $5.57 \pm 2.04$ & $2.98 \pm 0.44$ & $1.79 \pm 0.34$ \\
\hline Balagonj & $0.04 \pm 0.04$ & $2.10 \pm 0.19$ & $0 \pm 0.00$ & $4.70 \pm 0.35$ & $5.60 \pm 0.52$ & $0.80 \pm 0.19$ \\
\hline Subornochar & $2.68 \pm 0.48$ & $7.07 \pm 0.93$ & $6.51 \pm 1.54$ & $16.08 \pm 0.88$ & $12.96 \pm 1.37$ & $2.51 \pm 0.39$ \\
\hline Companigonj & $6.12 \pm 0.78$ & $21.95 \pm 3.01$ & $25.48 \pm 6.31$ & $40.85 \pm 17.81$ & $25.57 \pm 13.34$ & $5.37 \pm 0.87$ \\
\hline Nikhongchari & $2.56 \pm 0.67$ & $3.00 \pm 1.13$ & $0 \pm 0.00$ & $5.44 \pm 1.36$ & $0.78 \pm 0.57$ & $0 \pm 0.00$ \\
\hline All mean & $1.26 \pm 0.09$ & $3.57 \pm 0.32$ & $2.54 \pm 0.48$ & $8.62 \pm 1.21$ & $5.45 \pm 0.88$ & $1.41 \pm 0.15$ \\
\hline
\end{tabular}

\subsubsection{The Distribution of Sheep Population According to Sex and Age Groups}

Table 4 shows the distribution of sheep population in irrespective of the study areas. The herd size of sheep per household was found $13.27 \pm 1.23$, where the number of ram, ewe, whither, lamb (male) and lamb (female) were $1.55 \pm 0.13,7.49 \pm 0.74,0.53 \pm 0.07,1.61 \pm 0.15$ and $2.08 \pm 0.23$ respectively. However, the percentage of ram, ewe, whither, lamb (male) and lamb (female) were $11.71 \%, 56.47 \%$,
$4.00 \%, 12.09 \%$ and $15.70 \%$ respectively. Among all types of sheep, ewe percentage was the highest because farmers normally kept ewes for further reproduction and ram and wither were sold early in the market most of the cases. Moreover, the highest herd size of sheep was found in Copanigonj upazila $(76.61 \pm 8.90)$ followed by Subonochar (30.71 7.26) upazila and the lowest was in Tangail sadar upazila (3.73 \pm 0.18$)$. Companigonj and Subornochar upazilas were found the most sheep concentrate areas because of char and river areas. 
Table 4. Distribution of sheep population according to sex and age groups.

\begin{tabular}{lllllll}
\hline Upazila & Sheep (Mean \pm SE) & Ram (Mean \pm SE) & Ewe (Mean \pm SE) & $\begin{array}{l}\text { Wither } \\
(\text { Mean } \pm \text { SE) }\end{array}$ & $\begin{array}{l}\text { Lamb (Male) } \\
(\text { Mean } \pm \text { SE) }\end{array}$ & $\begin{array}{l}\text { Lamb (Female) } \\
(\text { Mean } \pm \text { SE) }\end{array}$ \\
\hline Naogaon Sadar & $100 \%$ & $11.84 \%$ & $48.49 \%$ & $14.53 \%$ & $12.16 \%$ & $12.95 \%$ \\
& $(6.84 \pm 0.29)$ & $(0.81 \pm 0.05)$ & $(3.32 \pm 0.17)$ & $(0.99 \pm 0.08)$ & $(0.83 \pm 0.08)$ & $(0.89 \pm 0.08)$ \\
Mohadevpur & $100 \%$ & $15.82 \%$ & $52.32 \%$ & $1.50 \%$ & $13.79 \%$ & $16.15 \%$ \\
& $(6.07 \pm 0.32)$ & $(0.96 \pm 0.07)$ & $(3.17 \pm 0.19)$ & $(0.11 \pm 0.03)$ & $(0.84 \pm 0.07)$ & $(0.98 \pm 0.08)$ \\
Gaibandha Sadar & $100 \%$ & $15.12 \%$ & $53.37 \%$ & $3.62 \%$ & $12.12 \%$ & $15.75 \%$ \\
& $(4.44 \pm 0.19)$ & $(0.67 \pm 0.07)$ & $(2.37 \pm 0.11)$ & $(0.16 \pm 0.04)$ & $(0.54 \pm 0.05)$ & $(0.70 \pm 0.07)$ \\
Gobindogonj & $100 \%$ & $21.22 \%$ & $56.27 \%$ & $6.68 \%$ & $8.21 \%$ & $7.62 \%$ \\
& $(7.11 \pm 0.37)$ & $(1.51 \pm 0.10)$ & $(4.00 \pm 0.16)$ & $(0.48 \pm 0.11)$ & $(0.58 \pm 0.08)$ & $(0.54 \pm 0.10)$ \\
Tangail Sadar & $100 \%$ & $17.99 \%$ & $63.19 \%$ & $2.24 \%$ & $10.02 \%$ & $6.54 \%$ \\
& $(3.73 \pm 0.18)$ & $(0.67 \pm 0.07)$ & $(2.36 \pm 0.14)$ & $(0.08 \pm 0.03)$ & $(0.37 \pm 0.07)$ & $(0.24 \pm 0.05)$ \\
Bhuapur & $100 \%$ & $16.86 \%$ & $51.82 \%$ & $2.85 \%$ & $13.09 \%$ & $15.37 \%$ \\
& $(4.37 \pm 0.23)$ & $(0.74 \pm 0.06)$ & $(2.26 \pm 0.12)$ & $(0.12 \pm 0.04)$ & $(0.57 \pm 0.07)$ & $(0.67 \pm 0.08)$ \\
Sylhet Sadar & $100 \%$ & $21.96 \%$ & $66.67 \%$ & $0.45 \%$ & $3.45 \%$ & $7.47 \%$ \\
& $(5.25 \pm 0.42)$ & $(1.15 \pm 0.09)$ & $(3.50 \pm 0.36)$ & $(0.02 \pm 0.02)$ & $(0.18 \pm 0.04)$ & $(0.39 \pm 0.06)$ \\
Balagonj & $100 \%$ & $4.23 \%$ & $79.47 \%$ & $7.52 \%$ & $4.70 \%$ & $4.07 \%$ \\
Subornochar & $(3.89 \pm 0.28)$ & $(0.16 \pm 0.04)$ & $(3.09 \pm 0.22)$ & $(0.29 \pm 0.07)$ & $(0.18 \pm 0.03)$ & $(0.16 \pm 0.03)$ \\
& $(100 \%$ & $13.95 \%$ & $55.25 \%$ & $46.51 \%$ & $10.83 \%$ & $13.45 \%$ \\
Companigonj & $(30.71 \pm 7.26)$ & $(4.28 \pm 0.87)$ & $(16.97 \pm 4.44)$ & $(2.00 \pm 0.50)$ & $(3.33 \pm 0.77)$ & $(4.13 \pm 1.16)$ \\
& $100 \%$ & $6.29 \%$ & $57.12 \%$ & $0.78 \%$ & $14.71 \%$ & $21.09 \%$ \\
Nikhongchari & $(76.61 \pm 8.90)$ & $(4.82 \pm 0.54)$ & $(43.78 \pm 5.36)$ & $(0.60 \pm 0.23)$ & $(11.28 \pm 1.43)$ & $(16.17 \pm 2.11)$ \\
Overall & $100 \%$ & $20.00 \%$ & $46.00 \%$ & $0.00 \%$ & $6.50 \%$ & $18.46 \%$ \\
& $(7.22 \pm 0.80)$ & $(1.44 \pm 0.38)$ & $(3.33 \pm 0.47)$ & $(0 \pm 0.00)$ & $(1.11 \pm 0.31)$ & $(1.33 \pm 0.42)$ \\
& $100 \%$ & $11.71 \%$ & $56.47 \%$ & $4.00 \%$ & $12.09 \%$ & $15.70 \%$ \\
& $(13.27 \pm 1.23)$ & $(1.55 \pm 0.13)$ & $(7.49 \pm 0.74)$ & $(0.53 \pm 0.07)$ & $(1.61 \pm 0.15)$ & $(2.08 \pm 0.23)$ \\
\hline
\end{tabular}

\subsection{Housing Management of Sheep}

Most of the farmers found that they provided more or less housing facility for their sheep. From Figure 4, it was found that $86.88 \%$ of farmers provided the housing facility for sheep, although the housing management was found very poor. However, irrespective of the study areas rest $13.32 \%$ reared sheep in open place and fencing. Mostly cowshed $(21.50 \%)$ was used as the housing of sheep followed by dochalaghar (19.63\%) irrespective of the study areas. The sheep rearing farmers are less interested in spent money on housing rather than other purposes [7]. Previously also found that the sheep management system is not commercial and keep their buck in the low-cost house which is made of the wooden or muddy floor, bamboo fence, the roof of straw and raise under scavenging condition. Moreover, the farmers keep sheep in an open house or open confined area without tethering during the night [13].

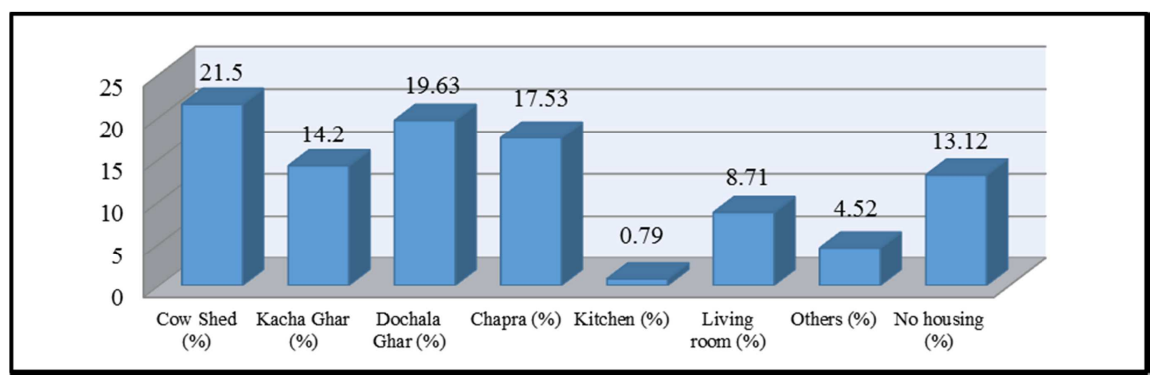

Figure 4. Different types of housing facility of sheep.

\subsection{Feeding System of Sheep and Feeding Time}

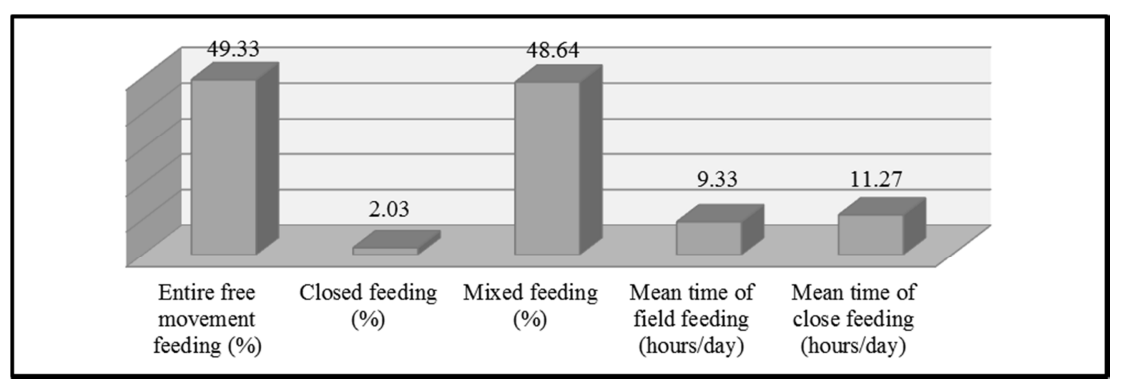

Figure 5. Feeding system and time spent on the feeding of sheep. 
The feeding system of sheep in the study areas was mostly the entire free movement system $(49.33 \%)$ followed by mixed feeding (both free and close feeding) (48.64\%) presented in Figure 5. The farmer practiced semi-intensive $(80 \%)$ which is similar to mixed feeding and extensive feeding system $(20 \%)$ similar to the entire free movement system found in the previous study [7]. However, the average field feeding and close feeding time of sheep was $9.33 \pm 0.05$ and $11.27 \pm 0.10$ hours/day respectively. A total of $40 \%$ of farmers are spending time to graze and feed their sheep is 10 hours/day which is almost the same as the present finding [14].

\subsection{Types of Pasture Land Used for Feeding}

Figure 6 shows the types of pasture land used by the sheep rearing farmers irrespective of areas. It was observed that $66.34 \%$ of farmers were used open land followed by $61.53 \%$ roadside as pasture land for their sheep. However, crop field (22.62\%), flood areas (15.38\%) and cultivated fodder (4.24) were also found in the study areas. Most of the farmers $(60 \%)$ used roadside grass found in the previous study which is almost similar to the present study [15].

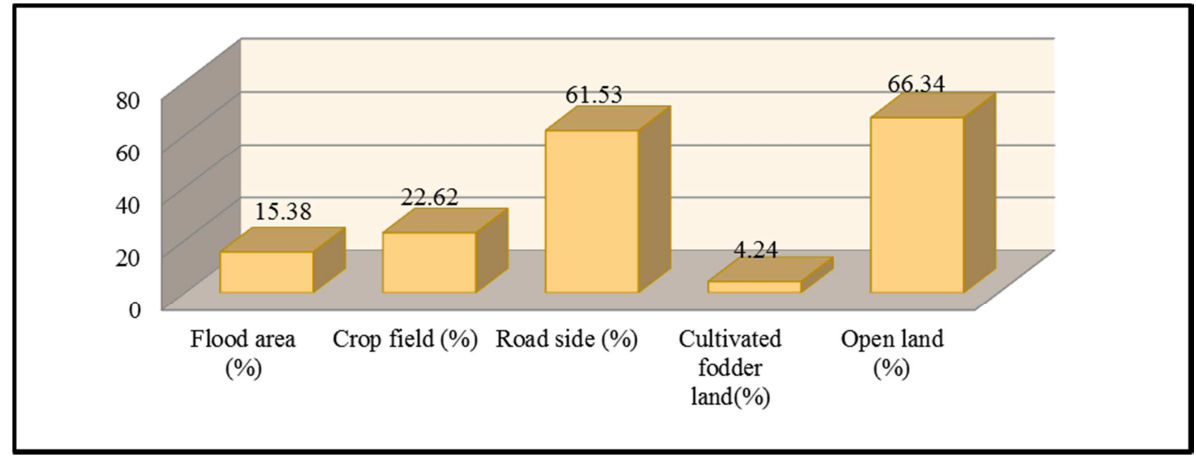

Figure 6. Types of pasture land used by the farmer in the study area.

\subsection{The Problems and Constraints Faced by Sheep Rearing Farmer}

The sheep rearing farmers were asked about the problems and constraints faced in rearing sheep in the study areas. Multiple numbers of problems and constraints were faced by the farmer presented in Figure 7. It was revealed that the highest $43.15 \%$ farmers reported about shortage of natural feeding land followed by disease and treatment $(41.00 \%)$ related problems. Previously found that the native sheep are usually raised upon natural feed resources and inadequate and poor quality feed resources which are main problems for sheep production [16]. However, lack of finance (23.30\%) was found a major constraint in rearing sheep. Moreover, high feed price, marketing problem, improved breed and training facility, died due to road accident, theft of sheep, unavailability of good quality ram, dog bite, low price of sheep, bad odour of sheep etc. problems were found faced by the farmers at the field level.

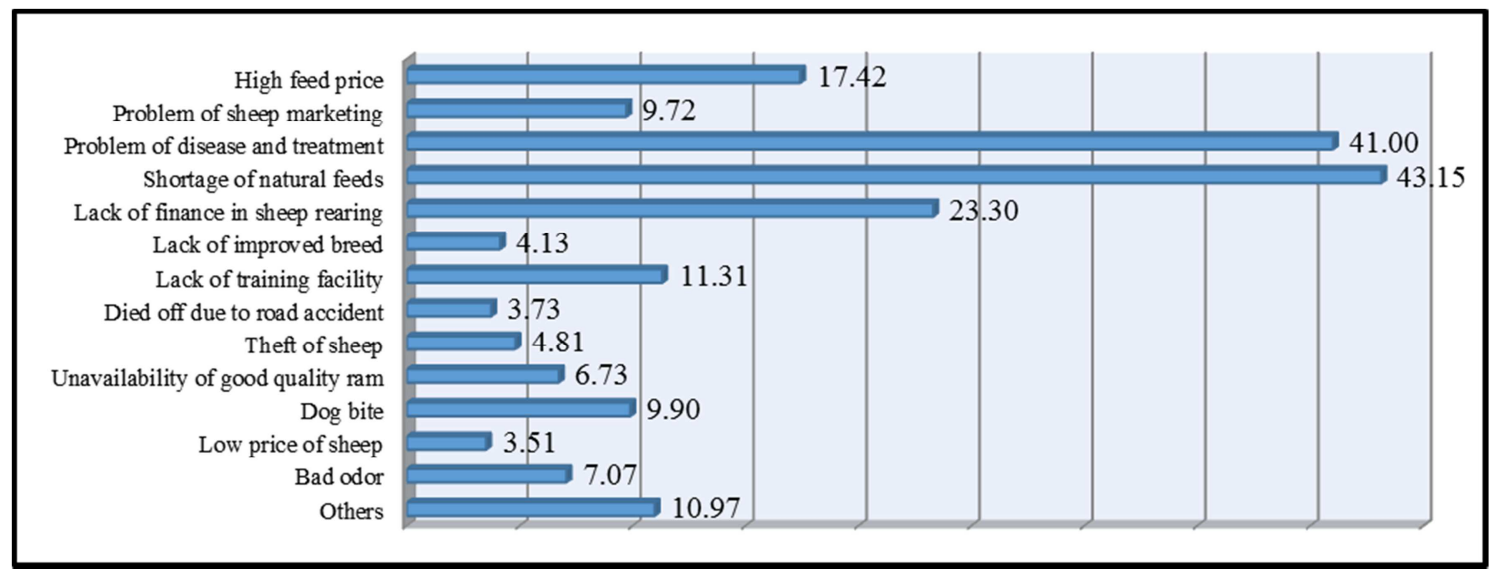

Figure 7. Problems faced by the sheep farmer.

\section{Conclusion}

From the research, it may be concluded that the literacy rate of sheep rearing farmer was found poor and the major dropout occurred in primary level. The literacy rate was better found in Nikhongchari and Subornochar upazilas. Most of the farmers $(65.16 \%)$ were involved in agriculture as their main occupation. The landholdings and annual income of the sheep farmers were found the highest in Subornochar and Companigonj upazila respectively. Subornochar and Copanigonj were found rich in livestock assets than the other 
surveyed area. However, the herd size per household was $13.27 \pm 1.23$ and the highest herd size was found in Copanigonj upazila $(76.61 \pm 8.90)$ followed by Subonochar (30.71 7.26) upazila. The housing facility was found poor and lack of separate improved housing facility found irrespective of the areas. The feeding system of sheep was found traditional and most of the farmers fed their sheep in the open field and roadside. The highest 43.15 and $41.00 \%$ farmers were facing problems related to the unavailability of natural feeds, disease and treatment. Emphasis should be given to improve sheep management practices for better production. The sheep rearing may be effective means to eradicate hardcore poverty through creating employment opportunity for rural poor people as well as empowerment of rural women in the context of Bangladesh.

\section{Conflict of Interest}

The authors declare that they have no competing interests.

\section{Acknowledgements}

The project entitled "Conservation and improvement of native sheep through community and commercial farming" (Component-A, Research 2nd phase), Bangladesh Livestock Research Institute, Dhaka, Bangladesh, has given the technical and financial support to conduct this research.

\section{References}

[1] Islam K. B. M. S., Ershaduzzaman M., Munsi M. N., Kabir M. H., Das S., Kabir M. H. B. (2016). Establishment of health management package for native sheep of Bangladesh. Res. Agric. Livest. Fish. 3: 151-155.

[2] BBS (2019), Yearbook of Agricultural Statistics of Bangladesh. Bangladesh Bureau of Statistics, Ministry of Planning, Government of the People's Republic of Bangladesh, Dhaka. Chapter 4, Agriculture: Crops, Livestock, Forestry and Fishery, pp: 187.

[3] Mansur M. A. A., Alam M. G. S., Jha P. K., Rimon M. A., Naher N. and Bari F. Y. (2018) Conception rate following intra-cervical artificial insemination using frozen semen at field level in indigenous sheep of Bangladesh. Asian J. Med. Biol. Res., 4 (1), 55-62; doi: 10.3329/ajmbr.v4i1.36822.

[4] Ahmed S., Rakib M. R. H., Yesmin M., Sultana N., Jahan N. and Ershaduzamman M. (2018). Evaluation of lamb production potentiality of the Barind, Jamuna river basin and coastal region sheep of Bangladesh under intensive management. Journal of Advanced Veterinary and Animal Research. 5 (1): 37-43.
[5] Sarker N. R., Habib M. A., Amin M. R., Yeasmin S., Tabassum F. and Yeasmin D. (2017). Feeds and fodder dynamics in selected river basins of Bangladesh. Bang. J. Anim. Sci. 46 (3): 206-214.

[6] Sultana N., Rakib M. R. H., Talukder M. A. I. and Hossain S. M. J. (2010). Effect of replacement of conventional concentrate in a rice straw diet by Moringa foliage on lamb production performance. Journal of Experimental Agriculture International, 15 (5): 1-14.

[7] Hossain M. A., Akhtar A., Easin M., Maleque M. A., Rahman M. F., Islam M. S. (2018). Women livelihood improvement through sheep (Ovis aries) rearing in Sirajganj district of Bangladesh. International Journal of Natural and Social Sciences, 5 (3): 01-08.

[8] Azizunnesa, Zohara B. F., Bari F. Y. and Alam M. G. S. (2014). Baseline Study of Reproductive Performances of Indigenous Rams in Bangladesh. Journal of Agriculture and Veterinary Science. 7 (6): 83-89.

[9] Tempelman K. A., Cardelino R. A., (2007). Preserving and developing unique animal genetic resources for future generations. Chapter 6, pp. 111-119.

[10] Islam S., Khatun M., Ershaduzzaman M., Khan M. A., and Yasmin S. (2018). Climate change, livestock production and income vulnerability- Bangladesh perspective. African Journal of Economics and Sustainable Development. 1 (1) pp: 1-12.

[11] Sharmin S., Islam M. S. and Hasan M. K. (2012). Socioeconomic Analysis of Alternative Farming Systems in Improving Livelihood Security of Small Farmers in Selected Areas of Bangladesh. The Agriculturists 10 (1): 51-63.

[12] Islam M. A., Hossain M. N., Chokraborti S. S., Rahman S., Tasnim A. and Zabir A. A. (2018). Socio-economic Profile of Goat Rearing Farmers and Their Management Practices in Sylhet. Bangladesh Journal of Agriculture and Ecology Research International. 15 (4): 1-10.

[13] Sarder M. J. U., Islam M. H., Moni M. I. Z., Jahan S. S., Aktar S. and Uddin J. (2015). Reproductive and productive performance of sheep of Rajshahi, Bangladesh insight about effects of genotype and parity. Bangladesh livestock journal. 1: 31-34.

[14] Islam F., Sumon M. R. A., Faruque M. O., Sarder M. A. and Hossain M. S. (2016). Breeding practices of Bangladeshi coastal sheep. International journal of business, social and scientific research. 4 (4): 324-327.

[15] Hossain M. A., Islam M. A., Akhtar A., Islam M. S. and Rahman M. F. (2018). Socio-economic status of sheep farmers and the management practices of sheepat Gafargaon upazila of Mymensingh district. International Journal of Natural and Social Sciences. 5 (4): 07-15.

[16] Salma U., Yasmin L., Siddique M. S. and Miah A. G. (2015). Effect of improved feeding on reproductive performance of sheep under traditional management system in char areas of Bangladesh. Journal of Science and Technology 13: 6-11. 